\title{
プラスチックの無電解銅めっきにおける コロイド溶液による活性化処理
}

\author{
岩井 正雄*, 真嶋 宏**, 粟倉 泰弘**

\section{Activation of Plastic with Mixed-Colloid Solutions in the Electroless Plating of Copper}

\author{
Masao IWAI*, Hiroshi MAJIMA** and Yasuhiro AWAKURA**
}

\begin{abstract}
The applicability of an activation method utilizing solutions of mixed hydroxide colloids was examined for the electroless plating of copper onto $\mathrm{ABS}$ plastic surfaces or sintered $\mathrm{MgO}$ disks. The main results are as follows :

1) The activation of ABS plastic with colloid solutions of $\mathrm{Ni}(\mathrm{OH})_{2}$ or $\mathrm{Cu}(\mathrm{OH})_{2}$ at $\mathrm{pH} 7.8$ was found to be insufficient or unattainable, whereas activation with mixed-colloid solutions of $\mathrm{Ni}(\mathrm{OH})_{2}$ and $\mathrm{Cu}(\mathrm{OH})_{2}$ was satisfactory.

2) The addition of neutral salts, such as $\mathrm{MgCl}_{2}$ and $\mathrm{NaCl}$, to mixed-colloid solutions of $\mathrm{Ni}(\mathrm{OH})_{2}$ and $\mathrm{Cu}(\mathrm{OH})_{2}$ enhanced the activation. By contrast, the addition of $\mathrm{MgSO}_{4}$ or $\mathrm{Na}_{2} \mathrm{SO}_{4}$ had no effect on activation.

3) Copper films formed on ABS plastic, pre-activated with mixed-colloid solutions of $\mathrm{Ni}(\mathrm{OH})_{2}$ and $\mathrm{Cu}(\mathrm{OH})_{2}$, were sufficiently competitive to those activated by an ordinary $\mathrm{SnCl}_{2}-\mathrm{PdCl}_{2}$ method.

4) The activation method using mixed-colloid solutions requires adequate adsorption ability of colloids onto the substrate and the adequate reducibility of colloids to metallic state using a reducing agent such as $\mathrm{KBH}_{4}$.

5) The mechanism of the process of activation of $\mathrm{ABS}$ plastic or sintered $\mathrm{MgO}$ disks can be explained by surface electrochemistry.
\end{abstract}

Key Words : Electroless Plating, Copper, Activation, Mixed Colloids

\section{1. 緒言}

無電解銅めっきに招ける活性化処理法 *1 として $\mathrm{SnCl}_{2}$ 括よび $\mathrm{PdCl}_{2}$ 溶液を用いる方法が厇く使用されて いる1。この方法は簡単でしかる確実な処理法であるが， 強いて言えば使用する試薬が高価であり，また $\mathrm{SnCl}_{2}$ 溶液がかなり不安定であることが難点といえよう。

このような $\mathrm{SnCl}_{2}-\mathrm{PdCl}_{2}$ 系の活性化処理に対して, $\mathrm{NiCl}_{2}$ の加水分解により調製したコロイド溶液を用いる 活性化処理法が提案されている2)。しかし著者らの追試 によれば，この活性化法により処理したブラスチック表 面に生成した無電解銅めっきは必ずしも満足できるもの ではない。また，安価な金属の水酸化物コロイドを利用 するといら考方方自体は興味深いものであり，今後の研 究の進展如何によっては, 工業的な実用化の可能性も考 えられる。

* 富山工業高等専門学校 (下930 富山県富山市本郷町13) Toyama National College of Technology (13, Hongocho, Toyama-shi, Toyama 930)

** 京都大学工学部（广６06 京都府京都市左京区吉田本町） Fac. of Eng., Kyoto Univ. (Yoshida -honmachi, Sakyoku, Kyoto-shi, Kyoto 606)
このような観点から，著者らは無電解銅めっきの活性 化処理法として 2 種の金属水酸化物コロイドの協同効果 を利用した活性化処理法を開発した。

本報文は，このような活性化処理法に関する研究結果 について詳述したものである。

\section{2. 実 験 方 法}

本研究で行った試料の無電解銅めっき工程は，特に断 わらない限り図 1 に示したフローチャートに従った。す なわち, エッチング, 活性化処理, 還元ならびに無電解 銅めっきからなる。

供試体としては市販の ABS プラスチックおよび $\mathrm{MgO}$ の焼結体を用いた。

所定寸法の ABS プラスチック（厚さ $3 \mathrm{~mm}$ )をシリコ ンゴム製のコネクターに取り付け，これを $95 \% \mathrm{H}_{2} \mathrm{SO}_{4}$ $500 \mathrm{~cm}^{3}, 85 \% \mathrm{H}_{8} \mathrm{PO}_{4} 150 \mathrm{~cm}^{3}, \mathrm{~K}_{2} \mathrm{Cr}_{2} \mathrm{O}_{7} 25 \mathrm{~g}, \mathrm{H}_{2} \mathrm{O} 350$ $\mathrm{cm}^{8}$ の組成のエッチング液 $200 \mathrm{~cm}^{8}$ に浸せきし，液温 $343 \mathrm{~K}$ において，約 $100 \mathrm{r} \cdot \mathrm{s}^{-1}$ の速度で20分間回転させ る。エッチング終了後水道水で十分に洗浄し，室温で乾

*1本報では，鋭敏化および活性化処理を併せて活性化処理と 呼ぶ。 


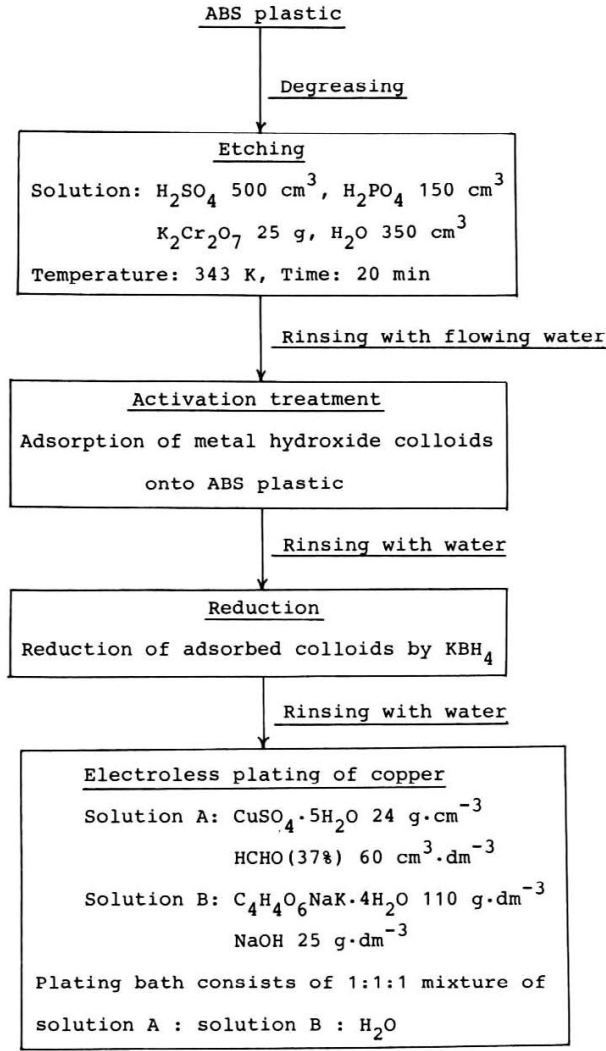

Fig. 1 Flowchart of the electroless plating of copper employed in this study

燥後活性化処理工程に供した。一方 $\mathrm{MgO}$ 焼結体の場合 には上記ェッチング夜では表面が荒れすぎるため，特に エッチングは行わなかった。

活性化処理は，次の操作で作製した $\mathrm{Ni}(\mathrm{OH})_{2}$ と $\mathrm{Cu}(\mathrm{OH})_{2}$ の混合コロイド溶液を用いて以下の順序で行 った。すなわち $0.2 \mathrm{~mol} \cdot \mathrm{dm}^{-3} \mathrm{NiSO}_{4}$ (または $\mathrm{NiCl}_{2}$ ) 打よび $0.2 \mathrm{~mol} \cdot \mathrm{dm}^{-3} \mathrm{CuSO}_{4}$ (または $\mathrm{CuCl}_{2}$ ) 溶液を体 積比で 1：2 の割合で混合し，自動滴定装置で 0.2 $\mathrm{mol} \cdot \mathrm{dm}^{-3} \mathrm{NaOH}$ を10秒間隔で間久的に $\mathrm{pH} 7.8$ にな るまで滴下する。このように調製した混合コロイド溶液 の $100 \mathrm{~cm}^{3}$ をれたビーカーを液温 $313 \mathrm{~K} に$ 保持した恒 温槽中に入れ，試料片を $200 \mathrm{r} \cdot \mathrm{s}^{-1}$ で回転させ20分間活 珄化処理を行う。その後純水で洗浄し，還元 5 分前に予 め調製し $298 \mathrm{~K}$ に保持した $1 \mathrm{~g} \cdot \mathrm{dm}^{-3} \mathrm{KBH}_{4}$ を含む $\mathrm{pH}$ 10.6 の溶液中に浸せきして，2 分間還元処理を行った 後脱イオン水で洗浄する。このようにして得た試料にホ ルマリンを還元剤とする銅めっき浴 ${ }^{3) * 2}$ を用いて液温 303-318 Kで無電解銅めっきを施した。なお，めっき中 は特に液のかくはんおよび循環は行わなかった。得られ た無電解銅めっき表面は走查電顕を用いて観察した他， 目的によっては活性化処理後の表面の元素分析も行った。 また試料体の表面電荷の測定には三田村理研侏製顕微鏡
電気泳動装置を使用した。

\section{3. 実 験 結 果}

\subsection{ABS プラスチックの活性化处理}

ABS プラスチックをエッチング，水洗後，別に 0.2 $\mathrm{mol} \cdot \mathrm{dm}^{-3} \mathrm{NiSO}_{4}$ にアルカリを加えて $\mathrm{pH} 7.8$ に調整し

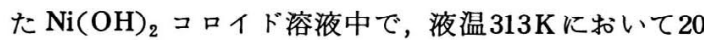
分間活性化処理を行い， $\mathrm{KBH}_{4}$ で還元した表面の分析結 果を図 2 に示す。プラスチック表面への Ni の沈着は認 められるが，沈着量は僅かであり，かつ偏在している。 またこのような処理を施した表面に無電解銅めっきを施 して得られためっき皮膜は部分的なものであって，試料 全面を被覆していない。 $\mathrm{Ni}(\mathrm{OH})_{2}$ 処理によるこのよう な不完全なめっき皮膜は，コロイド調製時のニッケル塩 濃度の増大 $\left(>0.4 \mathrm{~mol} \cdot \mathrm{dm}^{-3} \mathrm{NiSO}_{4}\right)$ p液温の上昇 ${ }^{* 8}$ によって改善しらることが実験の結果明らかになったが 得られためっき皮膜は依然として満足できるものではな い。

これに対し, 同じュロイド溶液でも $0.2 \mathrm{~mol} \cdot \mathrm{dm}^{-3}$ $\mathrm{CuSO}_{4}$ から調製した $\mathrm{Cu}(\mathrm{OH})_{2}$ 単一のコロイド溶液によ る活性化処理では，還元後 $\mathrm{Cu}$ の生成は全く認められず， 従って無電解銅めっきの生成も認められなかった。

一方 $0.2 \mathrm{~mol} \cdot \mathrm{dm}^{-3} \mathrm{NiSO}_{4}$ 扰よび $0.2 \mathrm{~mol} \cdot \mathrm{dm}^{-3}$ $\mathrm{CuSO}_{4}$ 溶液を体積比 $1: 2$ で混合して調製した

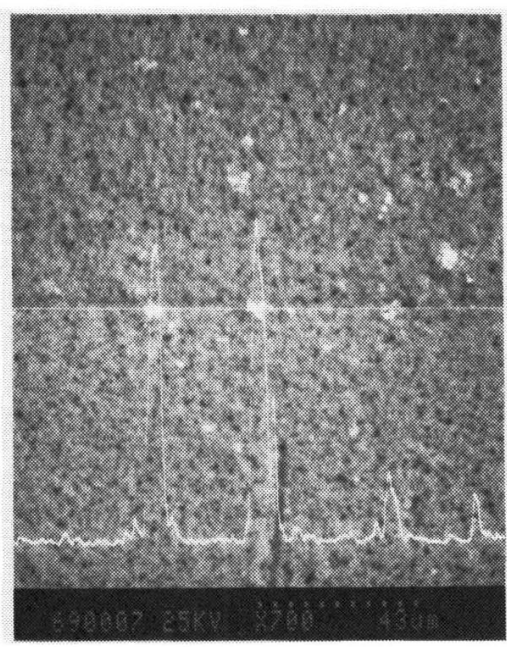

Fig. 2 Surface analysis of Ni on the surface of ABS plastic reduced with $\mathrm{KBH}_{4}$, which was pre-activated with $\mathrm{Ni}(\mathrm{OH})_{2}$ colloid solution

*2 A夜: $\mathrm{CuSO}_{4} \cdot 5 \mathrm{H}_{2} \mathrm{O} 24 \mathrm{~g} \cdot \mathrm{dm}^{-8}$ $\mathrm{HCHO}(37 \%) 60 \mathrm{~mL} / \mathrm{dm}^{-8}$

B夜 : $\mathrm{C}_{4} \mathrm{H}_{4} \mathrm{O}_{6} \mathrm{NaK} \cdot 4 \mathrm{H}_{2} \mathrm{O} 110 \mathrm{~g} \cdot \mathrm{dm}^{-8}$ $\mathrm{NaOH} 25 \mathrm{~g} \cdot \mathrm{dm}^{-\mathrm{s}}$

A 液 : B液 $: \mathrm{H}_{2} \mathrm{O}=1: 1: 1$ (体積比)

*3 液温の上昇は活性化処理には良好な結果をもたらすが，銅

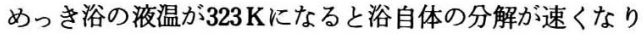
実用上好ましいものではない。 
$\mathrm{Ni}(\mathrm{OH})_{2}$ およよひ $\mathrm{Cu}(\mathrm{OH})_{2}$ の混合コロイド容液により， 前述と同じ条件下で活性化処理したプラスチック表面の 還元処理後の表面分析および銅めっき後の電顕写真を図 3 に示す。混合コロイド処理により極めて良好なめっき 皮膜が得られたことは写真に見られる通りであるが，皮 膜のはく離試験の結果も優れたものであった。このよう な混合コロイド溶液による活性化処理効果は $\mathrm{CuSO}_{4}$ と

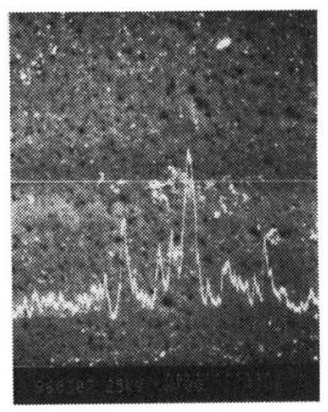

(a) $\mathrm{Ni}$

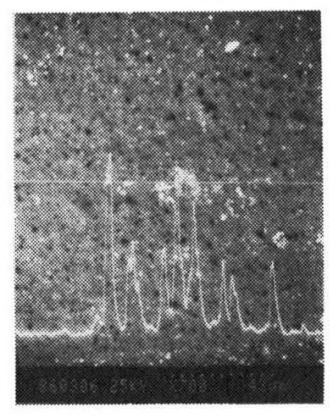

(a) $\mathrm{Cu}$

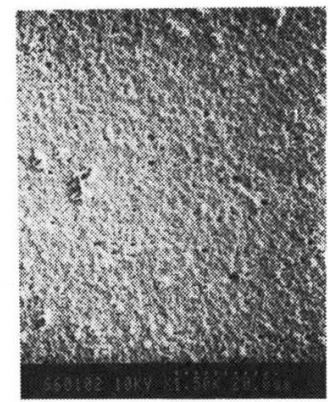

(b)

Fig. 3 (a)Surface analysis of $\mathrm{Ni}$ and $\mathrm{Cu}$ of the surface of ABS plastic reduced with $\mathrm{KBH}_{4}$, which was preactivated with a mixed-colloid solution of $\mathrm{Ni}(\mathrm{OH})_{2}$ and $\mathrm{Cu}(\mathrm{OH})_{2}$

(b)a scanning electron micrograph of the surface electroless-plated with copper

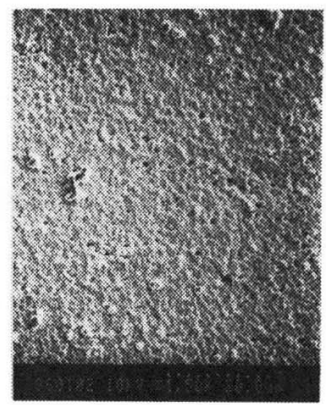

(a)

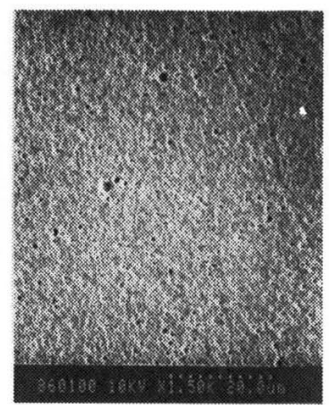

(b)
$\mathrm{NiSO}_{4}$ の代わりに $\mathrm{CuCl}_{2}$ と $\mathrm{NiCl}_{2}$ の混合塩化物溶液か ら調製したコロイド溶夜を用いてもよい。しかし，いず れの方法で調製した混合ュロイド溶液であっても, 活性 化時の液温をたとえば298K と室温近くに下げると，め っき皮膜の生成は部分的な不完全なるのとなる。一方, $\mathrm{CuCl}_{2}-\mathrm{NiCl}_{2}$ 混合溶液に $0.5 \mathrm{~mol} \cdot \mathrm{dm}^{-3} \mathrm{Mg} \mathrm{Cl}_{2}$ を添加 した場合には, 添加しない場合と比べ良好なめっき皮膜 が生成されたが，このことは $\mathrm{MgCl}_{2}$ 添加によるコロイ ドの凝析効果によるすのと思われる。 $\mathrm{MgCl}_{2}$ の代わりに $\mathrm{NaCl}$ を添加した場合その効果は認められるものの, そ の程度は小さいものであった。これに対し，同じ可溶性 の塩類であっても $\mathrm{Na}_{2} \mathrm{SO}_{4}$ や $\mathrm{MgSO}_{4}$ の添加の場合には, その影響は認められない。

\subsection{ABS プラスチック表面への銅めっきにおける混 合コロイド溶液による活性化処理法と従来法と の比較}

プラスチック表面に無電解銅めっきする場合, 従来は $\mathrm{SuCl}_{2}$ と $\mathrm{PdCl}_{2}$ を用いて活性化することが広く行われ， 良好なめっき皮膜が得られることが知られている1。本 研究に打ける混合コロイド活性化処理法で得られるめっ き皮膜が，従来法のそれと比較してそん色のないもので あれば, 混合コロイド法はその簡便さのために実用化も 可能と考兄られる。この点について検討を進めるため, 両法で得られためっき皮膜を比較した。

図4 は，混合コロイド活性化処理法および従来法で活 性化処理した後, 同一条件で無電解銅めっきした ABS ブラスチック表面の電顕写真を示したものである。活性 化処理拉よびめっき処理条件は写真の下に記載した通り であるが, 混合ュロイド活性化処理法によるものは, （c）で示した従来法のそれと比へ，（a）のものが光沢に おいて劣るものの, エッチング時間を10分間に短縮した (b)のものはむしろ良好であり，スコッチテーブを銅め っき表面に張り付けそれをはがす定性的なはく離試験に

Fig. 4 Scanning electron micrograph of the surface of ABS plastic electroless-plated with copper Temperature of plating bath : $313 \mathrm{~K}$, Time of plating : $10 \mathrm{~min}$

(a)Pre-activated with a mixed-colloid solution of $\mathrm{Ni}(\mathrm{OH})_{2}$ and $\mathrm{Cu}(\mathrm{OH})_{2}$ (Etching time : $20 \mathrm{~min}$ )

(b)Pre-activated with a mixed-colloid solution of $\mathrm{Ni}(\mathrm{OH})_{2}$ and $\mathrm{Cu}(\mathrm{OH})_{2}$ (Etching time : $10 \mathrm{~min}$ )

(c)Pre-activated with $\mathrm{SnCl}_{2}$ and $\mathrm{PdCl}_{2}$ (Etching time : $20 \mathrm{~min}$ ) 
おいてもそん色がなく従来法と同様に使用しうると考え られる。

\section{3 活性化可能なコロイドの組合せ}

前述の3.1拈よび3.2において, $\mathrm{Cu}(\mathrm{OH})_{2}$ と $\mathrm{Ni}(\mathrm{OH})_{2}$ の混合コロイド溶液を用いることにより, プラスチック が効果的に活性化されることを示したが, $\mathrm{Cu}(\mathrm{OH})_{2}-$ $\mathrm{Ni}(\mathrm{OH})_{2}$ 以外の組合せについてその可能性を知ること は重要と考えられる。

そこですべての金属塩濃度を $0.2 \mathrm{~mol} \cdot \mathrm{dm}^{-3}$ に保ち， 2 種の金属塩を等量になるように加光，上記の方法で混

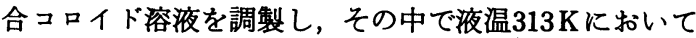
20分間活性化処理した ABS ブラスチック表面に前述の 方法で無電解銅めっきし，表面観察により活性化処理の 可能性を検討した。実験結果を表 1 に示す。表に明らか なよ 5 K, Ni (OH $)_{2}-\mathrm{Cu}(\mathrm{OH})_{2}, \mathrm{Ni}(\mathrm{OH})_{2}-\mathrm{Co}(\mathrm{OH})_{2}$, $\mathrm{Co}(\mathrm{OH})_{2}-\mathrm{Cu}(\mathrm{OH})_{2}$ の組合せで活性化が可能であり， $\mathrm{Cu}(\mathrm{OH})_{2}-\mathrm{Zn}(\mathrm{OH})_{2}, \mathrm{Cu}(\mathrm{OH})_{2}-\mathrm{Mn}(\mathrm{OH})_{2}, \mathrm{Cu}(\mathrm{OH})_{2}-$ $\mathrm{Al}(\mathrm{OH})_{3}$ 等では不可能であった。

\section{$3.4 \mathrm{MgO}$ 焼結体上への無電解銅めっきにおける混 合コロイド活性化処理法の適用}

混合コロイド活性化処理法がブラスチックに有効に適 用できることは前述の通りであるが，この方法がブラス チック以外の材質へも適用可能であるか否かを知ること は，その適用範囲を知るらえで重要である。そこで

Table 1 Combination of the mixed-colloid solution of metal hydroxides in the electroless plating of copper onto $\mathrm{ABS}$ plastic and the quality of plating

\begin{tabular}{c|c|c|c|c|c|c|c|c}
\hline & $\mathrm{Cu}$ & $\mathrm{Pb}$ & $\mathrm{Ni}$ & $\mathrm{Co}$ & $\mathrm{Cd}$ & $\mathrm{Zn}$ & $\mathrm{Mn}$ & $\mathrm{Al}$ \\
\hline $\mathrm{Cu}$ & $\times$ & & & & & & & \\
\hline $\mathrm{Pb}$ & $\triangle$ & $\times$ & & & & & & \\
\hline $\mathrm{Ni}$ & $\bigcirc$ & & $\bigcirc$ & & & & & \\
\hline $\mathrm{Co}$ & $\bigcirc$ & & $\bigcirc$ & $\bigcirc$ & & & & \\
\hline $\mathrm{Cd}$ & $\triangle$ & $\times$ & & & $\times$ & & & \\
\hline $\mathrm{Zn}$ & $\times$ & $\times$ & $\times$ & $\times$ & $\times$ & $\times$ & & \\
\hline $\mathrm{Mn}$ & $\times$ & & $\times$ & $\times$ & & & $\times$ & \\
\hline $\mathrm{Al}$ & $\times$ & & $\times$ & $\times$ & & & & $\times$ \\
\hline
\end{tabular}

() : Good, $\bigcirc$ : Poor, $\triangle$ : Very poor, $\times$ : Fail
$\mathrm{MgO}$ の焼結体を選び，前述の方法と同じ混合コロイド 活性化処理を行い，液温313K，めっき時間15分の条件 下で無電解銅めっきを行い，表 2 に示す結果を得た。す なわちエッチングを施さない $\mathrm{MgO}$ を $\mathrm{Ni}(\mathrm{OH})_{2}$ コロイ ド容液で活性化した場合にはほとんどめっきされないの に対し, $\mathrm{Cu}(\mathrm{OH})_{2}$ 単一あるいは $\mathrm{Ni}(\mathrm{OH})_{2}-\mathrm{Cu}(\mathrm{OH})_{2}$ 混 合コロイド溶夜で活性化した場合には不完全ながらめっ きが可能であった。

\section{4. 実験結果の検討}

温度 $313 \mathrm{~K}, \mathrm{pH} 7.8$ の $\mathrm{Ni}(\mathrm{OH})_{2}$ コロイド溶液により 20分間活性化処理し，水洗したブラスチック表面を $\mathrm{KBH}_{4}$ で還元後通常の無電解銅めっきを行ったが，この ような処理によって負弱ではあるが皮膜が得られ，また 還元後の試料表面の分析結果も Ni の存在を示してい た。 $\mathrm{Ni}(\mathrm{OH})_{2}$ のゼ口電荷点 (pzc) としては $\mathrm{pH}$ 值で9.85 -11.3の值が報告されている4)。また著者らは電気泳動 法により供試ブラスチックの表面電位を測定し, $\mathrm{pH} 7.8$ では負に帯電していることを明らかにした。従って活性 化処理過程で $\mathrm{Ni}(\mathrm{OH})_{2}$ コロイドがブラスチック表面上

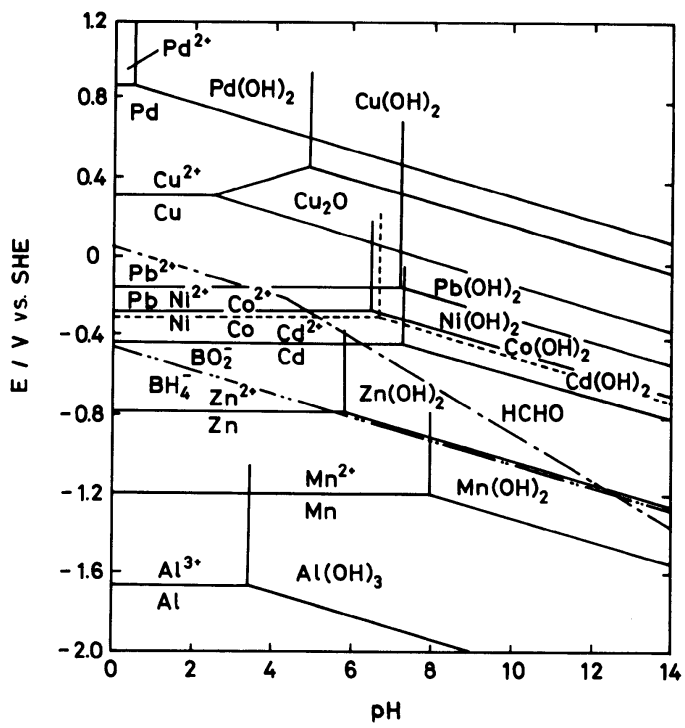

Fig. 5 Potential-pH diagram of the metal water systems $\left(\mathrm{a}_{\left.\mathrm{M}^{2+}=0.2\right)}\right.$

Table 2 Possibility of electroless plating of copper onto the sintered disk of $\mathrm{MgO}$ pre-activated with colloid solution (without etching)

\begin{tabular}{c|l|c}
\hline \multirow{2}{*}{ Sample } & Activation treatment of solution & $\begin{array}{l}\text { Possibility of electroless plating of } \\
\text { copper }\end{array}$ \\
\hline \multirow{3}{*}{$\begin{array}{c}\text { Sintered disk } \\
\text { of } \mathrm{MgO}\end{array}$} & $\begin{array}{l}\mathrm{Ni}(\mathrm{OH})_{2} \text { colloid solution } \\
\mathrm{pH} 7.8\end{array}$ & Almost impossible \\
\cline { 2 - 3 } & $\begin{array}{l}\mathrm{Cu}(\mathrm{OH})_{2} \text { colloid solution } \\
\mathrm{pH} 7.8\end{array}$ & \multicolumn{1}{c}{ Possible but poor } \\
\cline { 2 - 3 } & $\begin{array}{l}\mathrm{Ni}(\mathrm{OH})_{2}-\mathrm{Cu}(\mathrm{OH})_{2} \text { mixed- } \\
\text { colloid solution, } \mathrm{pH} 7.8\end{array}$ & Possible but poor \\
\hline
\end{tabular}


に静電的に凝集沈着した可能性が考えられる。しかし図 5 に示した電位-pH 図*4 からも予測できるように, $\mathrm{Ni}(\mathrm{OH})_{2}$ の $\mathrm{Ni}$ への還元電位が低いことから $\mathrm{KBH}_{4} に$ よる還元後の試料表面上への $\mathrm{Ni}$ 析出量は必ずしも十分 ではないと考学られる。事実表面分析の結果もこのよう な考え方が妥当であることを示している。また $\mathrm{Ni}(\mathrm{OH})_{2}$ コロイド自体と試料表面との結合力も水和コ ロイドを考劣れば比較的弱いと考えられる。この結合力 の増強には液温の上昇, コロイド濃度の増大, 金属塩添 加による凝析効果の増強などの利用が有効と考えられる。 事実, たと充ば0.1あるいは $0.2 \mathrm{~mol} \cdot \mathrm{dm}^{-3} \mathrm{NiSO}_{4}$ 溶液 を $\mathrm{pH} 7.8$ に調整したコロイド溶液により, 液温 $313 \mathrm{~K}$ で活性化処理した場合に得られる銅めっき皮膜は不完全 であるのに対し， $0.4 \mathrm{~mol} \cdot \mathrm{dm}^{-8} \mathrm{NiSO}_{4}$ の溶液から調製 したコロイド溶液を使用した場合には比較的良好なめっ き皮膜が得られた。また活性化処理時に打ける液温の上 昇，あるいは $\mathrm{MgCl}_{2}$ 添加も有効であることを確めてい るが，これらの事実は表面電気化学的な考え方の妥当性 を支持するものであろら。

一方, pH 7.8 で調製した $\mathrm{Cu}(\mathrm{OH})_{2}$ コロイド溶液によ り処理したプラスチック上には， $\mathrm{KBH}_{4}$ による還元後の 表面分析でも $\mathrm{Cu}$ の生成は認められず，また銅めっきむ 不可能であった。 $\mathrm{CuO}$ の $\mathrm{pzc}$ は $\mathrm{pH}$ で6.9 と報告されて 扮り4), $\mathrm{Cu}(\mathrm{OH})_{2}$ のそれが $\mathrm{CuO}$ に対する值とほぼ同一 と仮定すれば，これらの結果も表面電位的な考え方で説 明できる。

これに対し $\mathrm{NiSO}_{4}$ と $\mathrm{CuSO}_{4}$ (または $\mathrm{NiCl}_{2}$ と $\mathrm{CuCl}_{2}$ ) を用いて pH 7.8 で調製した $\mathrm{Ni}(\mathrm{OH})_{2}-\mathrm{Cu}(\mathrm{OH})_{2}$ 混合コ ロイド溶液で処理後，水洗，還元したプラスチック試料 上には図了にみられるよらに，明らかに $\mathrm{Ni}$ 叔よび $\mathrm{Cu}$ の生成が観察された。また得られためっき皮膜も良好で あった。このような協同効果は $\mathrm{pH} 7.8$ の溶液中で正に 帯電した $\mathrm{Ni}(\mathrm{OH})_{2}$ コロイドと負に帯電した $\mathrm{Cu}(\mathrm{OH})_{2}$ がへテロ凝集し， $\mathrm{Ni}(\mathrm{OH})_{2}$ の pzc がかなり大きい值で あることから全体として正の電荷をもち、これが負に帯 電した試料表面上に沈着したと考学れば無理なく理解で きる。活性化処理におけるこのような協同効果は $\mathrm{Cu}(\mathrm{OH})_{2}$ と $\mathrm{Co}(\mathrm{OH})_{2}{ }^{* 5}$ の混合コロイド溶液による活 性化処理によっても認められた。

さらに, $\mathrm{Ni}(\mathrm{OH})_{2}-\mathrm{Co}(\mathrm{OH})_{2}$ 系混合コロイド溶液を用 いて $\mathrm{pH} 7.8$ で活性化処理しても, $\mathrm{Ni}(\mathrm{OH})_{2}$ 単一のコロ イド溶液の場合よりも良好な活性効果が得られることを 見いだしているが、このような系の活性効果は

*4この電位-pH 図の作成にあたっては Latimer の成書 ${ }^{5}$ に 記載の熱力学的数値を使用した。

*5 $\mathrm{Co}(\mathrm{OH})_{2}$ の pzc として pH8. 3-11.4 の值が報告されてい る)。
$\mathrm{Ni}(\mathrm{OH})_{2}-\mathrm{Cu}(\mathrm{OH})_{2}$ 系や $\mathrm{Co}(\mathrm{OH})_{2}-\mathrm{Cu}(\mathrm{OH})_{2}$ 系のそれ とは異種の協同効果と考えられる。すなわち $\mathrm{Ni}(\mathrm{OH})_{2}$ と $\mathrm{Co}(\mathrm{OH})_{2}$ は共に $\mathrm{pH} 7.8$ で正に帯電しているはずで あり,これはプラスチック試料のそれとは異種の帯電で ある。このことは $\mathrm{Ni}(\mathrm{OH})_{2}$ と $\mathrm{Co}(\mathrm{OH})_{2}$ の両者とも試 料表面に沈着する可能性を示唆しているが，それらの共 沈着の結果活性化効果が現れたとすれば,これも一種の 協同効果と考えるべきであろう。

一方，表 1 に示したように $\mathrm{Co}(\mathrm{OH})_{2}$ と近いpzc 值を もつ $\mathrm{Al}(\mathrm{OH})_{3}{ }^{4)}$ と $\mathrm{Co}(\mathrm{OH})_{2}$ との混合系，あるいは $\mathrm{Al}(\mathrm{OH})_{3}-\mathrm{Ni}(\mathrm{OH})_{2}$ 系などでは協同効果は認められない。 これは，図５に示した電位-pH 図からもわかるよらに $\mathrm{Al}(\mathrm{OH})_{3}$ の $\mathrm{Al}$ への還元電位が低過ぎるために $\mathrm{KBH}_{4}$ によっては還元されず,むしろ $\mathrm{Al}(\mathrm{OH})_{3}$ が $\mathrm{Co}(\mathrm{OH})_{2}$ や $\mathrm{Ni}(\mathrm{OH})_{2}$ の吸着サイトを占めるため, $\mathrm{Co}(\mathrm{OH})_{2}$ や $\mathrm{Ni}(\mathrm{OH})_{2}$ の単一コロイドの場合よりも活性化を妨害す るためと考えられる。さらに $\mathrm{Pb}(\mathrm{OH})_{2}$ コロイド溶液で はたとえ吸着が起こったとしてもこれが触媒毒として働 くため効果が現れなかったことも考えられる。

このような考え方の妥当性を検討寸るために, ABS ブラスチックの代わりに pzc 值が13.4 4) の $\mathrm{MgO}$ 焼結体 上への, $\mathrm{pH} 7.8$ に調製した $\mathrm{Ni}(\mathrm{OH})_{2}$ コロイド溶液を用 いて活性化処理したところ無電解銅めっきが不可能であ ったのに対し, $\mathrm{Cu}(\mathrm{OH})_{2}$ または $\mathrm{Cu}(\mathrm{OH})_{2}-\mathrm{Ni}(\mathrm{OH})_{2}$ 二 ロイド溶液による処理は不十分ながら可能であった。こ の結果はこれらの活性化処理により $\mathrm{Cu}(\mathrm{OH})_{2}$ が吸着 し， $\mathrm{KBH}_{4}$ により還元され，銅めっきの基盤を築いたと 考学ると前述の考方方と矛盾しない。

次に $\mathrm{Cu}(\mathrm{OH})_{2}-\mathrm{Ni}(\mathrm{OH})_{2}$ 混合コロイド溶液による活 性化処理に際して, 可溶性塩として $\mathrm{NaCl}$ を添加した場 合には僅かではあるが活性効果が改善されるのに対し， $\mathrm{MgCl}_{2}$ の添加はその影響が大きい。このような現象は 可溶性塩添加によるコロイドの凝析効果として考えれば 納得しうるものである。これに対し $\mathrm{Na}_{2} \mathrm{SO}_{4}$ または $\mathrm{MgSO}_{4}$ を添加しても活性作用には特に効果が現れない。 これは,これらの硫酸塩の安定度定数としてイオン強度 0 に扎いてかなり大きな值が報告されている゙ ように, $\mathrm{Na}_{2} \mathrm{SO}_{4}$ や $\mathrm{MgSO}_{4}$ が安定であることならびに金属水酸 化物粒子が $\mathrm{SO}_{4}{ }^{2-}$ を特異吸着することにより $\mathrm{pzc}$ が変化

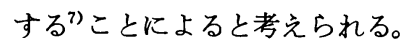

\section{5. 結言}

ブラスチックの無電解銅めっきの際の活性化処理法と して，2 種の金属水酸化物混合コロイドの協同効果を利 用する方法を開発し，その適用性について検討した結果 次の諸点を明らかにした。

1. ABS プラスチックを $\mathrm{pH} 7.8$ に調整した $\mathrm{Ni}(\mathrm{OH})_{2}$ または $\mathrm{Cu}(\mathrm{OH})_{2}$ コロイド溶夜を用いて活性化处理する 
と，活性化は不十分または不可能であったのに対し，両 者の混合コロイド溶液を用いた場合にはその活性効果は 十分に満足できるものであった。

2. $\mathrm{ABS}$ ブラスチックを $\mathrm{Ni}(\mathrm{OH})_{2}$ 扰よび $\mathrm{Cu}(\mathrm{OH})_{2}$ 混 合コロイド溶液で活性化する場合, $\mathrm{MgCl}_{2}$ のような中性 塩の添加は活性化作用を強めるのに対し, 同じ中性塩で あっても $\mathrm{Na}_{2} \mathrm{SO}_{4}$ や $\mathrm{MgSO}_{4}$ の添加は効果的でない。

3. $\mathrm{Ni}(\mathrm{OH})_{2}$ 扎よび $\mathrm{Cu}(\mathrm{OH})_{2}$ 混合ュロイド溶液で活性 化した ABS プラスチック表面に生成させた銅めっき皮 膜は, $\mathrm{SnCl}_{2}-\mathrm{PdCl}_{2}$ を用いる従来法で活性化後無電解め っきしためっき皮膜と比較してそん色のあるものではな い。

4. 混合コロイド溶液による活性化処理法の具備すべき 条件としては, コロイドの基体への吸着性と吸着コロイ ドの $\mathrm{KBH}_{4}$ のような還元剤による還元性が共に良好な ことが挙げられる。

5. ABS プラスチックや $\mathrm{MgO}$ 焼結体の混合コロイド 溶液による活性化機構は表面電気化学の立場から説明し らると考えられる。
謝辞

本報文の作成に当たり，東北大学選鉱製錬研究所 $⿴$ 井進之助教授ならびに姫路工業大学 鷹野修教授より有 益なご助言を賜った。ここに記して深謝の意を表す。

(1986-11-19 受理)

文献

1）友野理平；プラスチックめっき実務読本，p. 91 (オーム 社, 1969)

2) N. Feldstein ; U.S. Pat. 4, 048, 354 (1977)

N. Feldstein ; U.S. Pat. 4, 131, 699 (1978)

N. Feldstein ; U.S. Pat. 4, 180, 600 (1979)

3）松永正久，萩生田善明，伊藤 候; 金属表面技術, 19, 223 (1968)

4）虫明克彦, 増子 昇; 生産研究, 29, (1), 2 (1977)

5) W.M. Latimer ; Oxidation Potentials (2nd ed.) (Prentice Hall, 1952)

6) Stability Constants of Metal-ion Complexes, Part AInorganic Ligands, IUPAC Chemical Data Series, (21), 164 (Pergamon Press, 1982)

7) D.W.Fuerstenau and H.J. Modi ; J. Electrochem.Soc., 106, 336 (1959)

D.W. Fuerstenau and H.J. Modi ; J. Phys. Chem., 61, 640 (1957) 